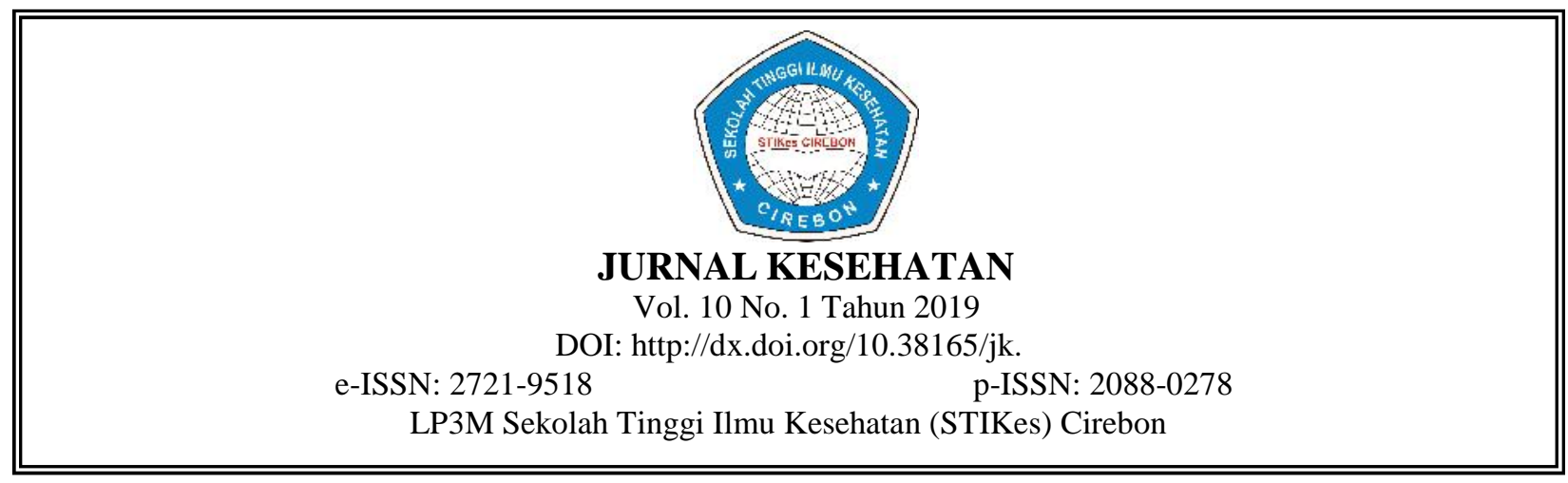

\title{
EFEKTIFITAS MODERN DRESSING TERHADAP PROSES PENYEMBUHAN LUKA DIABETES MELITUS TIPE 2
}

\author{
Endang Subandi* \\ Program Studi Ilmu Keperawatan Sekolah Tinggi Ilmu Kesehatan Cirebon \\ endang.subandi02@gmail.com \\ Kelvin Adam Sanjaya** \\ Program Studi Ilmu Keperawatan Sekolah Tinggi Ilmu Kesehatan Cirebon
}

\begin{abstract}
Abstrak
Luka Diabetes merupaka luka kronis yang susah disembuhakan. Luka diabetes berasal dari komplikasi penyakit diabetes. Luka diabetes sebagian besar dilakukan tindakan amputasi dan memiliki dampak kepada psikologi pasien. Sudah lama perawatan luka menggunakan konvensional yang memiliki kekurangan, seperti: menimbulkan rasa nyeri, menimbulkan luka baru, resiko infeksi lebih tinggi. Metode yang baru teknik perawatan luka modern dressing dimana luka akan dibuat moisture balance atau lembab karena akan memfasilitasi chemokines dan cytokines untuk pertumbuhan sel pada luka. Penelitian ini bertujuan untuk mengetahui efektifitas modern dressing terhadap proses penyembuhan luka diabetes mellitus tipe 2. Jenis penelitian menggunakan Pre-Postest With Control Group Desain terhadap suatu kelompok. Pengambilan sampel menggunakan accidental sampling dengan jumlah sampel sebanyak 15 responden intervensi dan kontrol. Pengumpulan data dilakukan dengan observasi, Instrument penelitian yang digunakan lembar observasi Betes-Jensen Wound Assessment Tool (BWAT). Penelitian dilakukan selama 45 hari. Analisa data yang digunakan adalah uji shapiro-wilk. Data analisa dengan uji statistik Wilcoxon test. Hasil penelitian didapatkan ada perbedaan skor luka sebelum dan sesudah pada kelompok pada kelompok perlakuan dengan $p$-value $=0.005(\leq 0.05)$ dan pada kelompok kontol dengan $p$-value $=1.000(\geq 0,05)$. Lalu hasil uji beda antar kelompok dengan $p$ value $=0,001(\leq 0,05)$. Jadi dapat disimpulkan bahwa modern dressing memiliki efektifitas terhadap proses penyembuhan luka diabetes bellitus tipe 2 .
\end{abstract}

Kata kunci: Luka, DM Tipe 2, Modern Dressing

\begin{abstract}
Diabetic wound are the chronic wounds that are difficult to cure. Diabetic wounds originate from complications of diabetes mellitus. Diabeteic wound are mostly implementation is amputation and have impact on the psychology of patients. Long time a wound treatment has deficiencies, causes pain, raises new wound, high risk of infection. New methods of modern dressing wound care tecniques where wound will be made moisture balance or moiist because it will facilitate chemokines and cytokines for cell growth in wounds. Therefore this study aims to determine the effectiviness of modern dressing on the wound healing process of type 2 diabetes mellitus. This type of research uses the Pre Postest With Control Group Desig for a sampling group conducted at Cirebon Wound Care Center using accidental sampling. The samples was 15 respondents treatments and control. Research instrument used were sheets observation Betes Jensen Wound Assessment Tool. The Study was conducted for 45 days. The data analysis used is the shapiro wilk test and data analysis sattistic with wilcoxon test. The result are obtained before and after in the treatment group with $p$ value $=0.005$ ( $\leq 0.05$ and in the control group with $p$ value $=1.000(\geq 0,05)$. Then the result of different test between groups with a value =0,001 $(\leq 0,05)$. The conclusion is a modern dressing has the effectiviness of the wound healing process of type 2 diabtes mellitus.
\end{abstract}

Kata kunci: Diabetic Wound, Type 2 Diabetes Mellitus, Modern Dressing 


\section{PENDAHULUAN}

Diabetes merupakan gangguan metabolisme ditandai dengan tingginya kadar gula dalam darah atau hiperglikemi yang ada kaitannya dengan abnormalitas metabolisme terhadap kerbohidrat, lemak dan protein yang disebabkan kerena tubuh tidak bisa mengsekresi insulin atau penurunan sensitivitas insulin. Diabetes mellitus merupakan penyakit kronis yang sering ditemukan pada lanjut usia namun zaman sekarang deiabetes sendiri dapat ditemukan pada usia $\geq 15$ tahun, tetapi sampai saat ini diabetes kebanyakan terjadi pada orang dewasa hingga lansia. ${ }^{1}$

Menurut American Diabetes Association (ADA) ada 9 fokus diabetes, seperti manajemen perawatan berkelanjutan (ongoing care management), pendidikan dan memembantu manajemen diri diabetes (diabetes self-management education and support), terapi nutrisi (medical nutrition therapy), aktifitas fisik (physical activity), berhenti merokok (smoking cessation), imunisasi (immunization), masalah psikososial (Psychosocial issues), evaluasi medis yang komrehensif (comprehensive medical evaluation), dan komorbiditas (comorbidities). ${ }^{2}$ Sembilan fokus tersebut membantu pasien dalam membantu kondisi nutrisi, kesehatan, psikologi, fisik, dan juga mengubah gaya hidup pasien. Dengan fokus manajemen penanganan diabetes akan terus dievaluasi dan strategi perawatan komprehensif selanjutnya.

Diabetes merupakan masalah serius bagi negera-negara berkembang dan negara maju di dunia. WHO (World Health Organization) mengatakan bahwa pada tahun 2015, 415 juta orang dewasa dengan diabetes, kenaikan 4 kali lipat dari 108 juta di 1980an. Pada tahun 2040 diperkirakan jumlah diabetes akan meningkat menjadi 642 juta. Hampir $80 \%$ diabetes ada di negara berkembang yang berpenghasilan rendah dan menengah. Pada tahun 2015 juga persentase orang dewasa sebanyak $8,5 \%$ ( 1 diantara 11 orang dewasa menyandang diabetes). ${ }^{3}$

Atlas diabetes menunjukan bahwa saat ini ada sekitar 424,9 juta pasien diabetes melitus. Angka ini melebihi jumlah seluruh penduduk Indonesia. Asia menempati urutan ke 3 angka diabetes di dunia. Di Indonesia sendiri pada tahun 2017 menempati peringkat ke 6 di dunia berasama dengan Amerika serikat, India, China, Brazil Rusia, dan Meksiko. Dengan jumlah penderita diabetes di Indonesia sebesar 10,3 juta dan pada tahun 2045 angka penderita di Indonesia menjadi 16,7 juta. $^{4}$

Persentase angka kematian penderita diabetes di Indonesia merupakan tertinggi ke 2 setelah Srilangka. Dua pertiga orang dengan diabetes di Indonesia tidak mengetaui dirinya memiliki diabetes, dan berpotensi untuk mengakses layanan kesehatan dalam kondisi terlambat (sudah dengan komplikasi). ${ }^{3}$ Menurut hasil Rikesdas 2018 bahwa diabetes semakin tahun semakin naik. Pada tahun 2018 penyakit diabetes naik 1,5\% dari tahun 2013 di Jawa Barat. Peningkatan ini dipengaruhi oleh faktornya kurang pengetahuan, usia, jenis kelamin, lingkungan, dan juga pekerjaan. $^{5}$

Diabetes tipe 2 merupakan intoleransi karbohidrat yang ditandai dengan resistensi insulin, defisiensi relative (bukan absolut) insulin, kelebihan produksi glukosa hepar dan hiperglikemia, karena defisiensi insulin komplet jarang terjadi, ketoasidosis jarang terjadi, ketoasidosis jarang terjadi pada bentuk diabetes ini. ${ }^{6}$ Studi yang dilakukan IDF mendapatkan hasil $85-95 \%$ kasus diabetes tipe 2 di dunia yang diderita oleh orang dewasa. Prevalensi keseluruhan yang dikoreksi sesuai usia untuk diabetes tipe 2 da IGT dilaporkan meningkat secara berturut-turut, dari 6\% menjadi 7,3\% dan 7,5\% menjadi 8\% sepanjang 28 tahun (dari tahun 2007-2025). Peningkatan absolut terjadi pada jumlah populasi (dari 246 menjadi 380 dan 308 menjadi 418 juta populasi) berusia 20-79 tahun. $^{7}$

Komplikasi menahun Diabetes Mellitus di Indonesia terdiri dari nefropati 7,1\%, Penyakit jantung koroner $20,5 \%$, retinopati $10 \%$, neuropati $60 \%$ dan kaki diabetik $15 \%{ }^{8}$ Diabetes mellitus seringkali tidak menyadari adanya luka pada kaki, sehingga meningkatkan resiko luka menjadi lebih dalam (ulkus kaki) dan perlu melakukan tindakan amputasi. Diperkirakan $15 \%$ penderita diabetes melitus dalam perjalanan penyakitnya mengalami komplikasi luka diabetik terutama pada luka kaki diabetikum. Sekitar 14-24\% diantara penderita kaki diabetik memerlukan tindakan amputasi. Pemeriksaan kaki diperlukan bagi yang mempunyai luka diabetes maupun sebelum luka 
muncul. Beberapa pencegahan terjadinya luka pada penderita diabetes dianjurkan menggunakan sandal diabetes, menghindari benda tajam, memakai kaos kaki, dan sepatu sempit. ${ }^{9}$

Neuropati perifer merupakan kondisi kerusakan pada saraf tepi, saraf tepi merupakan yang merupakan saraf yang terpisah dari otak, saraf-saraf spinalis, sumsum tulang. Saraf tepi ada tiga tipe dan memiliki fungsinya masing-masing, seperti saraf otonom (gerak tubuh yang tidak sadar), saraf motoris (dimana gerak tubuh yang sadar, dan sensoris (mendeteksi sensai-sensasi pada tubuh, seperti panas, nyeri, dan tekanan). Dimana pada saat saraf tepi terkena pada kasus diabetes maka adanya gangguan pada tubuh yang terjadi pada ekstermitas bagian bawah. ${ }^{10}$ Amputasi merupakan dihilangkan bagian tubuh bagian ekstremitas sebagian atau total. Amputasi terjadi akibat terjadinya proses akut seperti traumatik dan kondisi kronik seperti penyakit vascular perifer atau diabetes. ${ }^{11}$ Diabetes menjadi masalah yang paling sering terlihat pada pasien-pasien yang terkena luka kronis maupun akut, seperti luka diabetes. Setiap 30 detik terjadi amputasi di seluruh dunia dan 60-80\% amputasi non-traumatik disebabkan oleh diabetes. Angka kematian akibat amputasi di Indonesia tahun 2008 menyatakan bahwa angka amputasi dan kematian akibat amputasi sebesar 23-32,5\% dan rata-rata pasien pasca amputasi hidup selama 23,8 bulan. ${ }^{12}$

Proses penyembuhan luka juga mempunyai tahapan spesifik yang dapat terjadi tumpang tindih. Fase penyembuhan luka dibagi menjadi tiga fase, seperti fase inflamasi, fase proliferasi atau epitelisasi, dan terakhir fase maturase atau remodeling. Setelah ketiga tahap fase itu dilalui makan proses penyembuhan akan terjadi dan jaringan luka akan sembuh seperti sebelumnya. Berdasarkan prevalensi terhadap penderita ulkus diabetik pada kaki. Dengan seiringnya perkembangan zaman, di kenal dengan teknik perawatan luka secara konvesional dan modern. Dimana perawatan luka dengan modern dressing lebih mampu menjadikan luka pada diabetes menjadi lebih cepat pulih karena melihat tingkat kelebaban dari luka tersebut. Metode perawatan luka yang berkembang saat ini ialah perawatan luka dengan menggunakan prinsip moisture balance, dimana disebutkan dalam beberapa literature lebih efektif untuk proses penyembuhan luka bila dibandingkan dengan metode konvesional. $^{13}$

Selama ini, anggapan bahwa luka cepat sembuh itu karena mengering. Namun sebenarnya bahwa lingkungan lembab yang seimbang pada luka memfasilitasi pertumbuhan sel-sel pada luka. Perawatan luka modern dressing menjaga suhu luka agar tetap lembab dan menjaga luka tidak terkontaminasi, dengan teknik moisture balance memfasilitasi chemokines dan cytokines untuk pertubuhan sel pada luka. Luka tidak boleh terlalu lembab karena akan menimbulkan maserasi pada tepi luka dan apabila tidak lembab maka akan terjadinya kematian pada sel-sel di permukaan luka. Pada dasarnya teknik ini mengoptimalkan kerja dari growth factors, neutrofil, fibroblast, protease, dan makrofag. ${ }^{12,14}$

Teknik rawat luka modern lebih efektif daripada konvesional yang dibuktikan dengan penelitian yang dilakukan oleh Werna Nontji, Suni Hariati, Rosydah Arafat Tahun 2015. Tentang “Teknik Perawatan Luka Modern Dan Konvensional Terhadap Kadar Interleukin 1 Dan Interleukin 6 Pada Pasien Luka Diabetik". Dengan ( $p$ value 0,00) dari 32 responden (16 sampel perawatan luka konvesional dan 16 sampel perawatan luka modern dressing) perawatan luka modern lebih efektif dari ekskresi sitokin interleukin 1 dan interleukin 6, pada perawatan luka konvensional interleukin 1 mengalami peningkatan yang menunjukan bahwa proses fase implamasi memanjang dan proses penyembuhan luka lambat. ${ }^{15}$

Menurut Umi M. Rahayu, Mariyono, et all. Dalam jurnal tahun 2018 tentang "Combination Of Modern And Bagging Therapy For Speed Up The Process Wound Healing Of Grade II Diabetic Ulcer Patient”. Dengan ( $p$-value 0,018) dari 25 responden dengan kontrol 11 responden yang tidak dilakukan dengan cara modern dressing dan yang di intervensi 14 responden menggunakan modern dressing dan dibantu dengan terapi ozon. Bahwa terapi modern dressing dengan ozon lebih bagus untuk mengurangi bakteri di sekitar luka dan kecepatan penyembuhan pada pasien ulkus diabetikum pada masa inflamasi. ${ }^{16}$

Menurut Maria Imaculata, Putri Ayu Utami, dan Ana Damayanti. Dalam jurnal tahun 2018 tentang "Efektivitas Perawatan Luka Teknik Balutan Wet-Dry Dan Moist Wound Healing Pada 
Penyembuhan Ulkus Diabetik". Dengan (p-value 0,004) dengan total 33 responden dibagi 18 responden menggunakan wet-dry dan 15 responden menggunakan perawatan luka moist wound healing. Ternyata setelah dilakukan penelitian didapatkan bahwa dengan teknik moist wound healing lebih cepat proses penyembuhan dari pada dengan menggunakan wet-dry. ${ }^{17}$

Peneliti melihat berdasarkan fenomena yang terjadi saat ini, bahwa masih ada angka luka diabetes di masyarakat sebanyak $15 \%$. Menandakan masyarakat masih belum mengerti adanya perawatan luka yang tepat dan sebagian masyarakat memilih perawatan luka konvensional dikarenakan mudah didapatkan alat dan bahan, bisa dilakukan secara mandiri, sedangkan teknik ini memiliki dampak negatif yang cukup banyak seperti: resiko infeksi tinggi, balutan cepat kering resiko menimbulkan luka baru dan balutan berbau. Berbeda dengan modern dressing yang mengandalkan kelembaban untuk proses penyembuhan luka dengan kelebihan menyerap eskudat dengan baik, tidak bau, mengefektifitas perawatan di rumah sakit. Namun ada kekurangannya balutan modern dressing alat dan bahan hanya di apotik-apotik tertentu, harga perawatan yang lumayan mahal, dilakukan perawat bersertifikat.

Peneliti membuat penelitian ini mengacu kepada tugas atau peran perawat sebagai pemberi asuhan keperawatan dan pendidik. Sebagaimana ditulis dalam Undang-undang Republik Indonesia Nomor 38 Tahun 2014 Tentang Keperawatan pada pasal 29 ayat 1 - 3 mengatakan bahwa praktik keperawatan bertugas sebagai, pemberi asuhan keperawatan, penyuluh dan konselor, pengelola layanan kesehatan, pelaksana, dan peneliti. ${ }^{18}$

Tujuan penelitian menganalisis efektifitas modern dressing terhadap proses penyembuhan luka diabetes mellitus tipe 2

\section{METODE PENELITIAN}

Rancangan penelitian yang digunakan untuk menuntun peneliti memperoleh jawaban terhadap penelitian dengan mengacu pada jenis penelitian yang digunakan. Dalam penelitian ini, peneliti menggunakan desain yang akan digunakan dalam penelitian ini adalah jenis penelitian desain Quasy Eksperiment dengan pendekatan Pre-Postest With Control Group Desain. ${ }^{19}$ Populasi adalah kumpulan dari individu atau objek atau fenomena yang secara potensial dapat diukur sebagai bagian dari penelitian. Populasi juga dapat diartikan sebagai target di mana peneliti menghasilkan hasil penelitian. ${ }^{19}$ Besaran populasi di dalam penelitian adalah pasien yang memiliki luka diabetes jangka waktu 3 bulan terakhir (September - November 2018) sejumlah 18 orang. Jumlah sampel 15 orang. Metode penelitian dengan teknik wawancara dan observasi. Instrumen penelitian merupakan alat yang akan digunakan untuk pengumpulan data. ${ }^{19}$ Dalam penelitian ini menggunakan SOP yang akan digunakan peneliti untuk mengamati pelaksanaan modern dressing. Untuk variabel proses penyembuhan luka diabetes tipe 2 diukur dengan menggunakan lembar observasi Bates-Jensen Wound Assessment Tool (BWAT).

Analisa univariat merupakan analisis untuk menjelaskan atau mendeskripsikan karakteristik setiap variabel penelitian. ${ }^{20}$ Pada penelitian ini, peneliti menganalisa proses penyembuhan luka diabetes melitus tipe 2 sebelum dan sesudah dilakukan modern dressing.

Analisa bivariat dilakukan untuk mengetahui adanya pengaruh modern dressing terhadap proses penyembuhan luka diabetes melitus tipe 2. Analisa bivariat menggunakan Uji Wilcoxon. Analisa bivariat yaitu melakukan uji beda antara pre dan post. Dikatakan ada pengaruh jika hasil uji beda didapatkan nilai $p$ value $<\alpha(0,05)$.

\section{HASIL PENELITIAN}

\section{Proses Penyembuhan Luka Diabetes Mellitus Tipe 2 Sebelum Diberikan Intervensi}

Berdasarkan hasil analisis data proses penyembuhan luka yang dialami oleh responden yang menjalani perawatan sebelum diberikan terapi modern dressing pada kelompok intervensi dan kelompok kontrol konvensional dengan 15 responden dapat dilihat pada tabel sebagai berikut:

Tabel 1. Distribusi proses penyembuhan luka Diabetes Mellitus Tipe 2 sebelum diberikan intervensi 


\begin{tabular}{ccccc}
\hline & \multicolumn{2}{c}{ Modern Dressing } & \multicolumn{2}{c}{ Konvesional } \\
\cline { 2 - 5 } & $\mathrm{N}$ & Persentase (\%) & $\mathrm{N}$ & Persentase (\%) \\
\hline Regenerasi Luka & 15 & 100 & 15 & 100 \\
\hline
\end{tabular}

Dari tabel 1 dapat diketahui bahwa proses penyembuhan luka yang dialami oleh responden yang menjalani perawatan sebelum diberikan modern dressing pada kelompok intervensi yang mengalami regenerasi luka sebanyak 15 responden (100\%), dan konvesional pada kelompok kontrol yang mengalami regenerasi luka sebanyak 15 responden $(100 \%)$.

\section{Proses Penyembuhan Luka Diabetes Mellitus Tipe 2 Sesudah Diberikan Intervensi}

Berdasarkan hasil analisis data proses penyembuhan luka yang dialami oleh responden yang menjalani perawatan modern dressing pada kelompok intervensi dan konvesional pada kelompok kontrol dengan 15 responden dapat dilihat pada tabel sebagai berikut:

Tabel 2. Distribusi Proses Penyembuhan Luka Diabetes Mellitus Tipe Sesudah Diberikan Intervensi

\begin{tabular}{ccccc}
\hline & \multicolumn{2}{c}{ Modern Dressing } & \multicolumn{2}{c}{ Konvesional } \\
\cline { 2 - 5 } & $\mathrm{N}$ & Persentase (\%) & N & Persentase (\%) \\
\hline Regenerasi Luka & 7 & 46,7 & 15 & 100 \\
\hline Jaringan Sehat & 8 & 53,3 & & \\
\hline
\end{tabular}

Dari tabel 2 dapat diketahui bahwa proses penyembuhan luka pada responden sesudah dilakukan modern dressing pada kelompok intervensi dengan jaringan sehat sebanyak 8 responden (53,3\%), regenerasi luka sebanyak 7 responden $(46,7 \%)$ dan pada kelompok kontrol konvensional dengan kategori regenerasi luka sebanyak 15 responden (100\%).

\section{Perbedaan Proses Penyembuhan Luka Sebelum Dan Sesudah Diberikan Intervensi Modern Dressing Pada Kelompok Perlakuan}

Tabel 3. Perbedaan proses penyembuhan luka sebelum dan sesudah intervensi modern dressing pada kelompok perlakuan

\begin{tabular}{ccccc}
\hline Variabel & Mean & SD & Min- max & P value \\
\hline Sebelum intervensi & 2 & 0,000 & 2 & 0,005 \\
\cline { 1 - 3 } Sesudah intervensi & 1,46 & 0,516 & $1-2$ & \\
\hline
\end{tabular}

Tabel 3 menunjukkan bahwa proses penyembuhan luka yang menjalani modern dressing sebelum diberikan modern dressing pada kelompok intervensi rata-rata 2 dan standar deviasi 0,000, sedangkan sesudah diberikan modern dressing pada kelompok intervensi diperoleh rata-rata 1,46 dan standar deviasi 0,516 .

Berdasarkan hasil uji statistik dengan uji hipotesis Wilcoxon, diperoleh $p$ value proses penyembuhan luka $\mathrm{p}=0,005$ ( $p \leq 0,05)$. Maka dapat disimpulkan bahwa adanya perbedaan yang signifikan antara nilai proses penyembuhan luka sebelum dan sesudah pemberian intervensi modern dressing

\section{Perbedaan Proses Penyembuhan Luka Diabtes Mellitus Tipe 2 Dengan Modern Dressing Antar Kelompok} berikut:

Berdasarkan hasil pengukuran proses penyembuhan luka dengan dapat dihasilkan sebagai

Tabel 4. Perbedaan proses penyembuhan luka diabetes mellitus tipe 2 dengan modern dressing antar kelompok 


\begin{tabular}{ccccc}
\hline Variabel & Mean Rank & SD & Min- max & $P$ value \\
\hline Sesudah intervensi & 11.50 & 0.516 & $1-2$ & 0,001 \\
\hline Sesudah kontrol & 19.50 & 0.000 & $1-2$ & \\
\hline
\end{tabular}

Tabel 4 menunjukkan bahwa pada kelompok intervensi diperoleh mean rank sebesar 11.50 dan standar deviasi 0,516 dan pada kelompok kontrol konvensional diperoleh mean rank sebesar 19.50

Hasil analisa data untuk menguji hipotesa dapat dilihat dari nilai hasil Mann-Whitney $U$-Test yaitu diperoleh $p$ value sebesar $0,001(\geq 0,05)$ yang berarti hipotesis diterima.

Penelitian ini telah menunjukkan bahwa variabel independen berupa modern dressing mempunyai pengaruh yang signifikan terhadap proses penyembuhan luka pada pasien diabetes mellitus tipe 2 Tahun 2019 yang menjalani modern dressing.

\section{PEMBAHASAN}

\section{Proses Penyembuhan Luka Diabetes Mellitus Tipe 2 Sebelum Diberikan Intervensi Pada Kelompok Perlakuan Dan Kelompok Kontrol}

Dari hasil penelitian didapatkan bahwa pasien sebelum dilakukan intrvensi dari 15 responden itu mengalami luka dengan kategori regenerasi luka sebanyak $100 \%$, baik pada kolompok perlakuan dan kelompok kontrol. Kedua kelompok menggunakan lembar observasi yang sama hal ini sejalan dengan penelitian sebelumnya menurut bahwa lembar observasi BWAT dapat digunakan untuk mengukur score luka yang diberikan perawatan luka konvesional dan juga perawatan luka modern. ${ }^{21}$ Lalu penelitian selanjutnya, perawatan luka modern lebih efektif dari sekresi sitokin interleukin 1 dan interleukin 6, pada perawatan luka konvensional interleukin 1 mengalami peningkatan yang menunjukan bahwa proses fase inflamasi memanjang dan proses penyembuhan luka lambat. ${ }^{15}$ Banyaknya kejadian amputasi pada pasien mengakibatkan pasien merasa takut untuk melakukan perawatan luka serta memeriksa kan lukanya ke rumah sakit atau tenaga kesehatan lainnya, padahal perawatan luka baik untuk proses kesembuhan luka tersebut agar dapat peningkatan kualitas hidup penderita. Butuhnya bina hubungan saling percaya pada saat mawal melakukan perawatan luka. Beberapa pasien ketakutan apa bila melakukan perawatan luka dikarenakan takut akan sakit, menerima kenyataan dan juga tindakan amputasi selanjutnya. Pada proses amputasi mengakibatkan dampak pada pasien fisik dan psikologis. Diperlukan asuhan keperawatan khusus untuk memenuhi kebutuhan fisik, spiritual, kultural dan emosi post amputasi yang tidak diharapkan atau tidak direncanakan. ${ }^{11}$

Beberapa kejadian luka biasanya mengalami infeksi, dimana infeksi tersebut disertai dengan tahap infalamasi. Dimana tahap infeksi biasanya terjadi adanya kemerahan, nyeri, hangat di sekitar luka bila di pegang dan adanya eksudat. Pada awal observasi perawat luka harus mengetahui katagori luka aman dan luka infeksi. Pada modern dressing diperkenalkan infection control dimana infeksi dikontrol agar tidak menimbulkan masalah dan menimbulkan kematian jaringan/sel bagi luka. Bila ada infeksi maka tindakan akan dilakukan, seperti kultur dan penggunaan dressing antimikronial seperti silver. Selama proses penurunan infeksi teknik modern menggunakan teknik persiapan dasar luka atau Wound Bed Preparation (WBP) persiapan dasar luka ini membantu proses penyembuhan luka dimana menciptakan lingkungan penyembuhan secara optimal dengan meningkatkan vaskularisasi yang baik, dasar luka dengan eksudat minimal atau bahkan tidak ada eksudat. Luka diabetes adalah luka kronik yang mengalami kegagalan progress dalam proses penyembuhan luka. WBP ini dapat dilakukan dengan cara menghilangkan sel-sel yang abnormal, menurunkan jumlah bakteri, mengurangi eksudat serta meningkatkan jaringan sehat, sehingga penyembuhan luka terjadi. ${ }^{22}$ Sedangkan perawatan luka konvensional tidak dilakukan WBP cenderung kepada hanya memberihkan luka dan debridement pada luka.

Berdasarkan penjelasan diatas, dapat disimpulkan bahwa reponden yang mengalami luka akibat diabetes mellitus memerlukan perawatan yang serius untuk menghindari kerusakan jaringan 
yang lebih parah, dan terutama menghindari amputasi atau menghilangkan bagian tubuh bagian ekstremitas sebagian atau total. Dimana pada luka konvesional banyaknya pasien di rujuk ke rumah sakit untuk tindakan amputasi karena banyaknya jaringan nekrosis, tetapi pada teknik modern dressing diperkenalkan teknik Wound Bed Preparation (WBP) dan unuk luka infeksi menggunakan teknik infection control, dimana luka dipersiapkan dengan menggunakan debridement secara autolysis atau conservative sharp debridement (CSWD) tanpa mengamputasi bagian yang nekrosis.

Perawatan luka modern sangat aman pada saat sebelum dilakukan tindakanan dikarenakan luka diobservasi dahulu baru dilakukan tindakan intensif dan tepat dikarenakan setiap luka memiliki karekteristik yang berbeda-beda, pada perawatan luka konvesional biasanya akan dilakukan amputasi pada ekstremitas yang terkena luka tanpa diobservasi terlebih dahulu. Perawatan luka modern memperhatikan psikologi pasien kedepannya dan meningkatkan kualitas hidup pasien. Beberapa pasien pun merasakan cemas berlebihan pada saat awal observasi dikarena paradigma atau persepsi pasien akan di amputasi, merasakan sakit pada saat perawatan dan menarik diri.

Butuhnya bina hubungan saling percaya agar pasien mau melakukan perawatan luka dikarenakan pasien takut untuk melakukan perawatan luka. Berikan edukasi kepada pasien cara perawatan luka dengan metode modern dressing karena metode ini aman dan baik untuk proses penyembuhan luka karena mengurangi rasa nyeri, balutan lembab, nyaman dan juga cost efektif. Dimana teknik perawatan luka menggunakan teknik WBP sebagai dasar untuk melakukan perawatan luka agar proses penyembuhan luka efektif dan tercapai sesuai targetnya

\section{Perbedaan Proses Penyembuhan Luka Diabetes Mellitus Tipe 2 Sesudah Intervensi Pada Kelompok Perlakuan Dan Kelompok Kontrol}

Setelah dilakukan intervensi selama 45 hari, hasil data penelitian menunjukkan bahwa kelompok kontrol yang menggunakan perawatan luka konvensional yaitu dengan kategori proses penyembuhan luka regenerasi luka sebanyak 15 responden atau masih tidak jauh beda diangkat pada saat observasi pertama. Sedangkan pada kelompok eksperimen yang diberikan intervensi modern dressing yaitu menunjukan bahwa proses penyembuhan luka dengan kategori regenerasi luka sebanyak 7 responden atau sekitar 46,7\% dan kategori jaringan sehat sebanyak 8 responden atau sebesar 53,3\%. Hasil penelitian lain mengatakan bahwa tingkat kepuasan pasien tinggi karena adanya pengaruh modern dressing terhadap proses penyembuhan luka. ${ }^{23}$ Hasil penelitian sebelumnya menggunakan metode perawatan konvesional menggunakan betadin dimana povidoneiodine tersebut mempunyai rasional menghilangkan mikroorganisme pada luka dan untuk proses penyembuhan pada luka, tetapi menurut penelitian Retno Danarti bahwa penggunaan betadin bersifat toxin yang mengakibatkan kerusakan fibroblast secara permanen yang mengakibatkan terhambatnya proses penyembuhan luka. ${ }^{24}$ Dan menurut Liu mengatakan bahwa penggunaan betadin didapatkan cytotoxic pada jaringan osteoblast, fibroblast, dan myoblast. ${ }^{25}$

Dimana pada saat melakukan metode modern dressing juga memiliki metode TIME management. ${ }^{22}$ TIME management juga sama seperti WBP tetapi TIME management ini dilakukan setelah melaksanakan WBP dimana luka diangjkat jaringan matinya, infeksinya dikontrol, menggunakan dressing yang tepat, dan menjaga atau support proses penyembuhan luka. Ada teknik 3M pada saat melakukan perawatan luka yaitu mencuci, membuang jaringan mati dan memilih balutan yang tepat.Setelah melakukan perawatan luka dengan metode modern dressing, luka semakin membaik dari luas permukaan luka, warna dasar luka, dan juga ukuran luka. Dikarenakan teknik modern dressing menjaga suhu luka agar tetap lebab dan menjaga luka tidak terkontaminasi, dengan teknik moisture balance memfasilitasi chemokines dan cytokinesuntuk pertubuhan sel pada luka. luka tidak boleh terlalu lembab karena akan menimbulkan maserasi pada tepi luka dan apabila tidak lembab maka akan terjadinya kematian pada sel-sel di permukaan luka. Pada dasarnya teknik ini mengoptimalkan kerja dari growth factors, neutrofil, fibroblast, protease, dan makrofag. ${ }^{12,14}$

Menurut hasil pembahasan diatas dapat disimpulkan bahwa teknik modern dressing unggul dalam hal proses penyembuhan luka dikarenakan pada teknik modern dressing ini diperkenalkan konsep lembab yang membantu sel-sel dapat hidup dan membentu terjadinya proses penyembuhan 
pada luka dan juga menggunakan TIME manegement membantu luka agar dapat teratasi, berbeda dengan konvensional yang membuat luka kering. Teknik modern dressing membuat pasien merasakan dampak positifnya yaitu luka semakin membaik dan tingkat kepuasan pasien yang baik. Beberapa pasien mengatakan senang dan baru memahami cara perawatan luka secara modern. Dimana pada teknik perawatan modern sangat teliti dan hati-hati pada saat pengerjaannya serta alat yang dipakai lengkap untuk menunjang proses penyembuhan luka. Pada teknik perawatan modern juga memperhatikan TIME management dimana ini elemen penting juga bagi proses penyembuhan luka. Beberapa pasien menyayangkan dahulunya melakukan perawatan secara konvensional yang menimbulkan nyeri pada saat pengerjaannya dan juga luka tidak kunjung membaik.

Dari pemamparan diatas teknik perawatan luka dengan modern dressing sangat baik dari hasil yang sudah diteliti adanya proses penyembuhan yang cepat dibandingkan perawatan konvensional yang proses penyembuhannya lambat. Lalu perawatan modern dressing aman bagi luka dan tidak menimbulkan luka baru berbeda dengan perawatan konvensional yang diman menggunakan betadin yang bersifat toxin serta menggunakan kasa yang mengakibatkan lengket pada luka yang menjadikan luka sukar untuk sembuh. Pada teknik modern dressing diperkenalkan cara penanganan $3 \mathrm{M}$ (mencuci luka, membuang jaringan mati, dan memilih balutan yang tepat) yang menjadikan proses penyembuhan luka efektif.

\section{Perbedaan Proses Penyembuhan Luka Diabetes Mellitus Tipe 2 Sebelum Dan Sesudah Intervensi pada kelompok perlakuan dan kelompok control}

Hasil pengujian Pengaruh menggunakan Wilcoxon pada kelompok perlakuan diperoleh nilai probabilitas ( $p$-value) sebesar 0,005 sehingga kesimpulan uji statistik adalah terdapat pengaruh terhadap proses penyembuhan luka diabetes mellitus tipe 2, sedangkan Hasil pengujian Pengaruh menggunakan Wolcoxon pada kelompk perlakuan diperoleh nilai probabilitas ( $p$-value) sebesar 1,000 sehingga kesimpulan uji statistik adalah tidak terdapat pengaruh terhadap proses penyembuhan luka diabetes mellitus tipe 2. Hasil panelitian diatas sejalan dengan penelitian sebelumnya yang mengatakan bahwa modern dressing lebih efektif dan berpengaruh terhadap proses penyembuhan luka. ${ }^{26}$ Teknik perawatan luka konvesional ini memiliki dampak negatif yang cukup banyak seperti: resiko infeksi tinggi, balutan cepat kering resiko menimbulkan luka baru dan balutan berbau. Berbeda dengan modern dressing yang mengandalkan kelembaban untuk proses penyembuhan luka dengan kelebihan menyerap eskudat dengan baik, tidak bau, tidak menimbulkan luka baru, mengefektifitas perawatan di rumah sakit. Namun ada kekurangannya balutan modern dressing alat dan bahan hanya di apotik-apotik tertentu, harga perawatan yang lumayan mahal, dilakukan perawat professional. Menurut beberapa hasil penelitian menyimpulkan bahwa perawatan menggunakan teknik modern dressing lebih efektif dan lebih baik untuk proses penyembuhan luka diabetes.

Pada dasaranya perawatan luka secara modern dressing lebih effektif dibandingakan perawatan luka konvesional dikarenakan penelitian sebelumnya yang mengatakanadanya pengaruh pada luka seperti: perubahan ukuran luka pada responden yang dilakukan perawatan luka, bertambahnya granulasi dan terbentuknya epitelisasi. ${ }^{27}$ sedangkan perawatan luka secara konvesional mengakibatkan cidera berulang pada luka pasien yang mengakibatkan proses penyembuhan yang lambat atau lama dikarenakan perawatan luka konvesional juga menggunakan kasa yang biasanya kasa tersebut menempel langsung pada luka. menurut penelitian sebelumnyab bahwa kasa yang lengket diakibatkan balutan kasa yang diberi $\mathrm{NaCl}$ menguap yang dapat menimbulakan kerusakan atau trauma ulang pada luka. ${ }^{28}$ Dapat disimpulkan dari atas bahwa dilihat dari hasil $p$ value kelompok perlakuan 0,005 dengan begitu terdapat pengaruh terhadap proses penyembuhan luka, sedangkan $\mathrm{p}$ value pada kelompok kontrol 1,000 tidak terdapat pengaruh pada proses penyembuhan luka. Dengan begitu bahwa perawatan luka modern dressing mempunyai pengaruh yang signifikan dalam proses penyembuhan luka diabetes mellitus tipe 2 .

Karena teknik modern dressing ini menjadikan luka lembab agar sel-sel pada tubuh dapat bekerja untuk proses penyembuhan luka dan luka dapat teratasi. Teknik modern dressing ini efektif 
karena banyaknya jenis balutan untuk luka dan setiap luka memiliki sifat atau kharakteristik yang berbeda-beda maka dari itu teknik mdern dressing ini lebih cepat terhadap proses penyembuhan luka dibandingkan dengan perawatan luka konvesional yang hanya menggunakan betadin, $\mathrm{NaCl}$, dan kasa. Proses penyembuhan luka dengan metode modern dressing lebih cepat karena balutan yang oklusif yaitu balutan yang tepat untuk luka agar tetap lembab dan terhindar dari bahaya mikroorganisme dari luar. Dapat dilihat dari pembahasan diatas bahwa adanya perbedaan sebelum dan sesudah dilakukan modern dressing dan efektif terhadap proses penymbuhan luka, berbeda dengan perawatan luka konvesional yang tidak efektif terhadap proses penyembuhan luka dibetes mellitus tipe 2.

\section{Perbedaan Proses Penyembuhan Luka Diabetes Mellitus Tipe 2 Dengan Modern Dressing Antar Kelompok}

Hasil pengujian hipotesis diperoleh nilai probabilitas ( $p$-value) sebesar 0,001 sehingga kesimpulan uji statistik adalah terdapat perbedaan terhadap proses penyembuhan luka diabetes mellitus tipe 2 di Cirebon Wound Care Center (CWCC) Tahun 2019. Sependapat dengan teori diatas menurut Rahayu, dkk, bahwa terapi modern dressing dengan ozon lebih bagus untuk mengurangi bakteri di sekitar luka dan kecepatan penyembuhan pada pasien ulkus diabetikum pada masa inflamasi. ${ }^{16}$ Begitu pula dengan penelitian yang dilakukan oleh Maria Imaculata, Putri Ayu Utami, dan Ana Damayantiyang menyebutkan setelah dilakukan penelitian didapatkan bahwa dengan teknik moist wound healing lebih cepat proses penyembuhan dari pada dengan menggunakan wet-dry. ${ }^{17}$ Dimana penanganan luka harus secara hati-hati dan juga teliti memilih balutan yang tepat untuk proses penyembuhan yang efektif. Kualitas penanganan balutan luka yang efektif, seharusnya memenuhi syarat sebagai berikut: Mudah dalam pemasangan (easy to apply), dapat menyesuaikan dengan bentuk tubuh (comformatibility), mudah melepaskannya (easy to remove), nyaman dipakai (comfortable to 'wear'), tidak perlu sering ganti balutan. ${ }^{10}$

Menurut Anik Muryani dalam buku perawatan luka modern (2015) mengatakan bahwa perawatan luka modern lebih efektif dibandingkan dengan perawatan luka konvesional dan manfaat yang didapat oleh pasien yaitu dapat mengurangi biaya perawatan, manfaat yang didapat oleh perawat adalah menghemat jam perawatan di Rumah Sakit dan meningkatkan kualitas pelayanan. Bisa dilihat kelebihan dan kekurangan perawatan luka konvesional dan modern dressing. Perawatan luka modern dressing menggunakan alat-alat modern seperti ozon dan infrared. Ozon berguna untuk menghilangkan bakteri dan mikroorganisme pada sekitar luka dan permukaan luka dan infrared berguna untuk menghangatkan disekitar luka yang mengkibatkan peredaran darah di sekitar luka menjadi lancar dan kebutuhnan nutrisi pada luka tercukupi. ${ }^{29}$

Metode perawatan luka modern dressing dirasaakan oleh psien dikarenakan setelah membandingkan dengan perawatan luka konvensional semua pasien percaya bahwa metode modern dressing lebih efektif dan hasil maksimal dibandingkan perawatan luka secara konvensional. Hal itu dapat dilihat dari hasil sebelum dan sesudah perawatan luka menggunakan konvensional dan modern. Menggunakan balutan secara modern dirasa nyaman, aman, dan melindung luka dari paparan bakteri dan mikroorganisme yang dapat mengenai luka. Dapat dilihat dari pemaparan diatas bahwa metode modern dressing effektif untuk proses penyembuhan luka dibandingkan dengan metode konvensional. Terlihat pada saat pasien membandingkan hasil dari perawatan luka konvensional yang sebelumnya pasien jalani serta setelah perawatan luka menggunakan teknik perawatan luka modern dressing dan hasilnya bahwa perawatan luka dengan metode modern dressing lebih bagus dan efektif untuk proses penyembuhan luka.

\section{SIMPULAN}

Dari 15 responden yang dibagi kedalam kelompok intervensi pada pasien diabetes mellitus tipe 2 seluruh responden berada dikategori regenerasi luka sebelum diberikan modern dressing.

1. Kelompok perlakuan dengan jumlah kategori jaringan sehat sebanyak 8 responden atau sekitar $53,3 \%$ dan regenerasi luka dengan jumlah responden sebanyak 7 responden atau sekitar 46,7\%, 
sedangkan pada kelompok kontrol dengan katagori regenerasi luka sebanyak 15 responden $100 \%$.

2. Ada perbedaan pada kelompok perlakuan modern dressing terhadap proses penyembuhan luka diabetes mellitus tipe 2 ( $p$ value $=0,005)$ dan tidak ada perbedaan pada kelompok kontrol konvensional terhadap proses penyembuhan luka diabetes mellitus tipe 2 ( $p$ value $=1,000$ ). Terdapat perbedaan antar kelompok perlakuan dan kelompok kontrol. Pada kelompok perlakuan didapatkan $p$ value sebesar 0,001 sedangkan pada kelompok kontrol didapatkan nilai $p$ value sebesar 1,000 .

\section{SARAN}

1. Bagi Intitusi Pendidikan

Diharapkan institusi dapat memasukan dalam kegiatan proses belajar dan mengajar serta menjadikan upgrade skill bagi mahasiswa dan tenaga pengajar tentang efektifitas perawatan modern dressing terhadap proses penyembuhan luka diabetes

2. Bagi Peneliti Lain

Diharapkan bagi peneliti selanjutnya dapat melanjutkan penelitian ini dan sebagai acuan untuk menambah pengetahuan dan upgrade skill tentang efektifitas moden dressing terhadap proses penyembuhan luka diabetes

3. Bagi Perawat

Perawat mampu melakukan asuhan keperawatan mandiri secara independent dengan menggunakan teknik modern dressing dan sebagai acuan untuk upgrade skill dan mengikuti workshop perawatan luka modern derssing untuk proses penyembuhan luka diabetes mellitus.

4. Bagi Klinik

Melakukan dokumentasi dan perawatan luka sesuai SOP yang berlaku dan meningkatkan SDM dengan cara upgrade skill dan workshop. Dan dapat merubah paradigma pasien bahwa luka diabetes tidak harus diamputasi.

5. Bagi Pasien

Melakukan senam kaki secara mandiri dan merawat kaki agar tidak timbul luka lagi dikemudian hari serta sering mengecek kaki minimal sebulan sekali.

\section{DAFTAR PUSTAKA}

1. Priscilla LeMone, Karen M. Burke, Gerene Bauldoff. Buku ajar keperawatan medikal bedah. Vol. 2 Edisi 5. Jakarta: Buku Kedokteran EGC; 2016.

2. American Diabetes Association. Standards of Medical Care In Diabetes-2016. Journal of clinical and applied research and education. Amerika. Sup. 3 Vol. 39; tahun Januari 2016. [Diakses tanggal 30 Desember 2018]. Tersedia dari www.diabetes.org/diabetescare

3. WHO (world Health Oganization). Diabetes fakta dan angka. [Diakses tanggal 24 oktober 2018]. Tersedia dari www.searo.who.int/indonesia/topics/8-whd2016-diabetes-facts-andnumbers-indonesian.pdf

4. IDF (International Diabetic Federation). Diabetes atlas. Edisi ke 8. Tahun 2017. [Diakses 20 November 2018]

5. Kementrian Kesehatan Republik Indonesia, Hasil utama Riskesdas 2018. [Diakses 6 November 2018]. Tersedia dari www.litbang.kemkes.go.id

6. L. Branshers, Valentina. Aplikasi klinis patofisiologi pemeriksaan \& manajemen.Edisi 2. Jakarta: Buku Kedokteran EGC; 2003.

7. Rudy Bilous dan Richard Donelly. Buku pegangan diabetes. Jakarta: Bumi Medika; 2014.

8. Lina Ema Purwanti, Sholihatul Maghfirah. Faktor risiko komplikasi kronis (kaki diabetik) dalam diabetes mellitus tipe 2. The Indonesian Journal of Health Science. Vol. 7 No. 1; Desember 2016 [Diakses tanggal 3 November 2018]. Tersedia dari: http://jurnal.unmuhjember.ac.id/index.php/TIJHS/article/view/382 
9. Moh Gifari S. Gambaran karakteristik luka dan perawatannya Di Klinik Perawatan Luka Griya Afiat Makassar. Skripsi. Makasar; Universitas Hasanuddin; Febuari 2018. [Diakses tanggal 14 Oktober 2018]. Tersedia dari : http://digilib.unhas.ac.id/

10. Tandra, Hans. Segala Sesuatu Yang Harus Anda Ketahui Tentang Diabetes Panduan Lengkap Mengenal Dan Mengatasi Diabetes Edisi Kedua dan Paling Komplit [e-book]. Jakarta. Edisi 2; Tahun 2017. [Diakses tanggal 15 Oktober 2018]. Tersedia dari: https://www.amazon.com/Segala-sesuatu-ketahui-tentang-DIABETES/dp/6020334767

11. LeMone, Priscilla, M. Burke, Karen dan Bauldoff, Gerene. Buku Ajar Keprawatan Medikal Bedah. Jakarta. Edisi 5 Vol. 4; tahun 2016

12. Maryunani, Anik. Perawatan Luka Modern [Modern Woundcare] Terkini Dan Terlengkap. In Median; 2015.

13. I Made Sukma Wijaya. Perawatan luka dengan pendekatan multidisiplin [e-book]. Edisi ke-1, Yogyakarta: ANDI (Anggota IKAPI); 2018.

14. Ronald W. Kartika. Perawatan Luka Kronis dengan Modern Dressing. Wound Care/Diabetic Center, RS Gading Pluit, Jakarta. Vol. 42 no. 7; tahun 2015 [Diakses tanggal 9 oktober 2018]. Tersedia dari: https://www.academia.edu/36224517/TeknikPerawatan_Luka_Kronis_dengan_Modern_Dressing

15. Werna Nontji, Suni Hariati, Rosyidah Arafat. Teknik Perawatan Luka Modern Dan Konvensional Terhadap Kadar Interleukin 1 Dan Interleukin 6 Pada Pasien Luka Diabetik. Jurnal Ners. April 2015; Vol 10 No 1: 133-137. [Diakses tanggal 9 Oktober 2018]. Tersedia dari : https://e-journal.unair.ac.id/JNERS/article/view/2105

16. Umi M. Rahayu, Mardiyono, et all. Combination of Modern Dressing and Bagging Ozone Therapy for Speed Up The Process Of Wound Healing of Grade II Diabetic Ulcer Patient. International Journal of Multidisciplinary and Research. Semarang; Poltekes Semerang; September 2018; Vol. 3: 01-05. [Diakses tanggal 1 Januari 2019]. Tersedia dari: https://www.ncbi.nlm.nih.gov/pmc/articles/PMC5350204/

17. Maria Imaculata, Ose, Putri Ayu Utami, Ana Damayanti. Efektifitas Perawatan Luka Teknik Balutan Wet-Dry Dan Moist Wound Healing Pada Penyembuhan Ulkus Diabetik. Journal of Borneo Holistic Health. 1 Juni 2018; Hal. 101-112. Borneo; Fakultas Ilmu Kesehatan Universitas Borneo Tarakan. [Diakses 1 Januari 2019]. Tersedia dari: http://jurnal.borneo.ac.id/index.php/borticalth/article/view/401

18. Subandi, Endang S.Kep., Ners., MH dan Abudarakhman, R. Nur, S.Kep., Ners., MH. Etika Dan Hukum Keperawatan. Cirebon: Deepublish;2015.

19. Notoatmodjo S. Metodologi penelitian kesehatan.Jakarta: Rineka Cipta; 2018.

20. Nursalam. Metodologi penelitian ilmu keperawatan pendekatan praktis edisi 3. Jakarta: Salemba Medika; 2013.

21. Rizki annisaR, Dewi gayarti. Analisis grade luka antara skala wagner dan BWAT pada pasien ulkus diabetikum. Juenal; FIK UI; 2015. [Diakses tanggal 2 April 2019]. Tersedia dari: http://lib.ui.ac.id/naskahringkas/2018-11/S59584-Rizki\%20Annis\%20Rahardhiany

22. Bauk, Ikram, Hamka, Kana, Edy, et al. Modul pelatihan perawatan luka 2019. Bogor: Yayasan Wocare Indonesia; 2019.

23. Elsya Maharani. Pengaruh teknik modern dressing terhadap proses penyembuhan luka dibetes di klinik perawatan luka griya assyifa kabupaten jember tahun 2015. Skripsi; universitas muhammadiyah jember; 2015. [Diakses tanggal 20 Desember 2018]. Tersedia dari: http://digilib.unmuhjember.ac.id/files/disk1/67/umj-1x-elysamahar-3339-1-artikel-1.pdf

24. Retno danarti, suwarda, et al. The effect povidone-iodine on the wound healing process: study on fibroblast populated collagen lattice (FPCL) Model. J Med Sci: Vol. 46 No. 3; september 2014. [Diakses tanggal 1 April 2019]. Tersedia dari: https://jurnal.ugm.ac.id/bik/article/view/7310

25. Liu. Human primary osteoblast, fibroblast, and myoblast werw expanded in cell culture and subject to various concentrations of PVP-I $(0 \%, 0.001 \%, 0.01 \%, 0.1 \%, 1 \%)$ for $3 \mathrm{~min}$, followed 
by A scrath assay to assess the effect of PVP-I on cell migration. Case Study; 2017. [Diakses tanggal 1 April 2019]. Tersedia dari : https://www.ncbi.nlm.nih.gov/pubmed/28505031

26. Moh. Gifari S. Gambaran karakteristik luka dan perawatannya di klinik perawatan luka Griya Afiat Makasar. Skripsi. Makasar; Universitas Hasanudin; 2015. [Diakses tanggal 14 Oktober 2018]. Tersedia dari : http://digilib.unhas.ac.id/

27. Yanti, handayani estrin, asriani. Aplikasi modern wound care dalam manajemen luka diabetes. Studi kasus. Magelang; Universitas Muhammadiyah Magelang; Desember 2016. [Diakses tanggal 25 febuari 2019]. Tersedia dari: http://103.215.25.50:46247/public/document/penelitian/53956-laporan-penelitian-aplikasimwc-pd-pasien-dm-2016.pdf

28. Dina Desi S.L.I, Desi Irawaty, Taufik Si Haryati. Modern Dressing Improve The healing process in diabetec wound, jurnal; 30 Mei 2017 [Diakses tanggal 1 April 2019]

29. Soemarjono, Arif. Terapi Pemanasan Infrared (IR). [Diakses tanggal 31 Desember 2018]. Tersedia dari: http://www.flexfreeclinic.com/detail-artikel2/terapi-pemanasan-infrared-ir-24 